International Journal of Current Advanced Research

ISSN: O: 2319-6475, ISSN: P: 2319 - 6505, Impact Factor: SJIF: 5.995

Available Online at www.journalijcar.org

Volume 6; Issue 4; April 2017; Page No. 3236-3238

DOI: http://dx.doi.org/10.24327/ijcar.2017.3238.0234

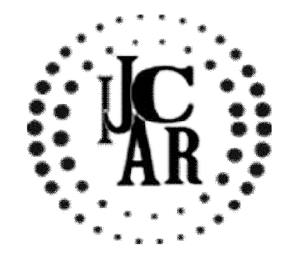

Research Article

\title{
AWARENESS AND ATTITUDE TOWARDS OBTURATION TECHNIQUES AND MATERIALS USED BY STUDENTS IN DENTAL COLLEGES OF TAMIL NADU
}

\author{
Jennifer Suhasini $\mathbf{S}^{1}$ and Manish Ranjan ${ }^{2}$
}

Department of Conservative Dentistry and Endodontics Saveetha Dental College and Hospitals

\begin{tabular}{l}
\hline A R T I C L E I N F O \\
Article History: \\
Received $11^{\text {th }}$ January, 2017 \\
Received in revised form $19^{\text {th }}$ February, 2017 \\
Accepted $22^{\text {nd }}$ March, 2017 \\
Published online $28^{\text {th }}$ April, 2017
\end{tabular}

Key words:

Obturation Techniques And Materials, Awareness And Attitude

\begin{abstract}
A B S T R A C T
Aim- The main aim of the study is to survey about the type of obturation technique that is most commonly followed by the students in dental colleges of Tamil Nadu.

Objective- To Investigate the endodontic profile of students and understand the most common obturation technique that is followed among students and the reason behind them following that particular technique.

Background- The attitudes, techniques and different approaches toward endodontic treatment reflects the quality of the root canal treatment performed by students in the dental colleges. The long term success of endodontic therapy depends not only on preoperative status of the pulp and periapical tissues but also on a number of procedure related factors.

Reason- To understand the attitude of various students in dental colleges towards various obturation techniques.
\end{abstract}

Copyright $\mathrm{C} 2017$ Jennifer Suhasini S and Manish Ranjan. This is an open access article distributed under the Creative Commons Attribution License, which permits unrestricted use, distribution, and reproduction in any medium, provided the original work is properly cited.

\section{INTRODUCTION}

The quality of root canal treatment is as important as its quantity. Dental schools must prepare their students to undertake uncomplicated root canal treatments of predictable quality upon graduation. Undergraduate curriculum guidelines have been formulated by the American Dental Association to define the acceptable standard of care in clinical endodontics[1]. Several studies, however, have reported that the majority of dentists are not in compliance with these guidelines[2-4]. These studies investigated the attitude of dentists in Western countries [5-7]. Other studies have investigated the attitude of general dental practitioners toward various aspects of endodontic treatment in developing countries [8-10]. The phases of root canal treatment are access opening, cleaning and shaping and obturation. It begins by removal of all the organic substrate from the canal. This includes removal of the coronal pulp tissue and radicular pulp tissue. The coronal pulp tissue is removed by performing complete access and identifying straight-line access to the radicular pulp tissue. This, in turn, allows the practitioner to remove the radicular pulp tissue with endodontic files and irrigation.Obturation is the most important step of root canal treatmentas it completely fills the canals and provides a three dimensional

*Corresponding author: Jennifer Suhasini S

Department of Conservative Dentistry and Endodontics

Saveetha Dental College and Hospitals seal preventing any further bacterial infectionto provide an impermeable fluid tight seal within the entire root canal system, to prevent oral and apical microleakage. It is important in any obturation technique that the filling material is very closely adapted to the root canals of the tooth. An ideal filling material should be the one with a good hermetic seal at the apical terminus so as to enhance the clinical success of the root canal treatment. Many techniques for obturation have been found and tested they include lateral condensation, vertical condensation, compaction, chemically or thermo plasticised gutta-percha techniques. They are usually gutta percha along with a sealer for obturation.

Therefore, the purpose of the present study was to gather information about the various aspects,materials and attitudes employed during root canal therapy performed by dental students in various dental colleges over South India.

\section{MATERIALS AND METHODS}

A survey was done among undergraduate and post graduate students of various dental colleges over Tamil Nadu which was formatted as a questionnaire consisting of various questions regarding the obturation techniques they follow and the materials they use during obturation and distributed to various colleges over Tamil Nadu. 300 questionnaires were collected from the students. The data collected was then tabulated and statistics were done, results were found. 


\section{RESULTS}

The participation rate is $100 \%$ with an overall sample size of 300 students mainly comprising of both undergraduate and post graduate students. From the data obtained results were formulated.

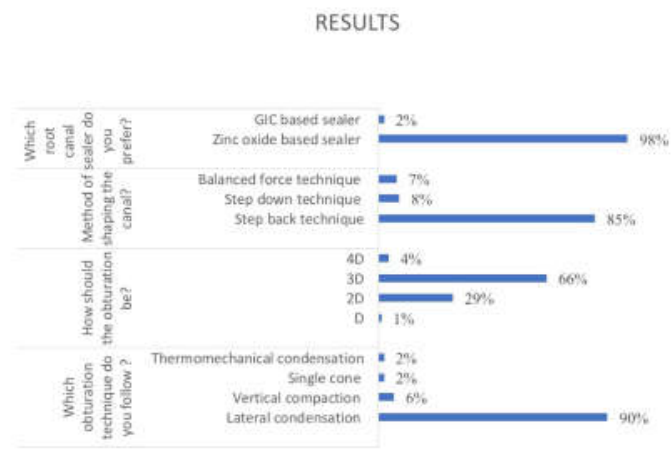

\section{DISCUSSION}

It is important to know about the attitude of the students towards the techniques and methods that are available for use. This study mainly aims to find out about the awareness of the students who are practising the technique and the reason why the follow it. Students were asked questions about the average number of Root canal treatment they perform per week and most (71\%) people answered that they perform about 1 root canal treatment per week. $18 \%$ of the students answered that they perform about 2 root canal treatments per week followed by $9 \%$ of students who perform up to 3 root canal treatments and $2 \%$ who perform up to 4 root canal treatments.

When asked about the type of obturation technique they follow $90 \%$ answered that they follow lateral condensation technique followed by $6 \%$ of them who use vertical compaction. About $2 \%$ of them follow single cone and thermomechanical condensation.Previous studies in India also state that lateral condensation $(61 \%)$ is the most common obturation technique that is followed among students and dental practitioners in India[13] From this we obtain that the students were not aware and did not have more knowledge about thermofill technique. They were not aware of the advantages other techniques of obturation give. The choice of isolation they follow is only rubber dam isolation. Other methods of isolation such as cotton roll isolation and saliva ejector are not used in their practise.Before obturation of the root canals the method they use to dry canals is only by paper points. They do not use other ways to dry canals like 3 way syringe or a cotton which is rolled over a file.About $66 \%$ of them answered that the obturation should be $3 \mathrm{D}$ but a reasonable amount $(29 \%, 1 \%)$ also answered that the obturation should be $2 \mathrm{D}$ and $\mathrm{D}$ respectively. From this it is aware that not all the students are aware that the obturation should be 3D. Awareness has to be created about how an ideal obturation should be. $85 \%$ of the students follow step back technique and Previous studies also show that the most commonly used technique of cleaning and shaping is step back technique (54\%) followed by step down technique [14] and they prefer the use of rubber dam isolation for a higher success rate of the treatment [15]. Only about $15 \%$ of the students followed other techniques like crown down technique, balanced force technique. All of them answered that they use only gutta percha to fill the canals and were not aware of the other materials that are available for obturation. They were not aware of the disadvantages of silver points. Most of them use only Zinc oxide eugenol based sealers which comprises of $98 \%$ of the total number of students. About $2 \%$ of them answered that they use GIC based sealers after obturation. Very few had knowledge about the other sealers that are available for use which had advantages over the currently used sealers. They were asked about the obturation related mishaps most of them were aware of the obturation related mishaps but they were only aware about mishaps like underfilling or overfilling of the root canal. Some of them were of vertical root fracture also.

There is currently lack of awareness about the various methods and materials that are available in Tamil Nadu. This study evaluates the attitude and awareness of students towards the materials and methods that are followed by dental students in various colleges of Tamil Nadu. Isolation of the tooth being treated is one of the important steps for ensuring clear working field and minimising the risk of infection. The use of rubber dam during endodontic treatment is considered essential as it helps in preventing several risks including salivary and bacterial contamination of the tooth being treated, accidental inhalation and ingestion of instruments and ingestion of irrigating solutions escaping into the oral cavity [12] . Clear conclusions related to some of the endodontic practices in the current study could not be arrived at for several questions as many respondents chose more than one option.

\section{CONCLUSION}

From this study, we conclude that lateral condensation is the most common technique followed by dental students in Tamil $\mathrm{Nadu}$, rubber dam isolation is preferred mostly by all the students. Step back technique for cleaning and shaping is the most common technique followed by students in various colleges over Tamil Nadu. Students were not aware of many obturation related mishaps that could happen during obturation. Thus, special educational programs need to be conducted and students need to be educated about the various materials and methods.A wider range of the study has to be conducted to arrive at a proper conclusion.

\section{References}

1. European Society of Endodontology. Undergraduate curriculum guidelines Undergraduate Curriculum Guidelines for Endodontology. Int Endod $J$ 2001;34:574-580.

2. Whitten BH, Gardiner DL, Jeansonne BG, Lemon RR. Current trends in endodontic treatment: report of a national survey. J Am Dent Assoc 1996; 127:133-141.

3. Jenkins SM, Hayes SJ, Dummer PM. A study of endodontic treatment carried out in dental practice within the UK. IntEndodJ 2001; 34:16-22.

4. Slaus G, Bottenberg P. A survey of endodontic practice amongst Flemish dentists. IntEndodJ 2002;35:759-767

5. Akpata ES. Endodontic treatment in Nigeria. IntEndod J 1984;17:139-151

6. Whitten BH, Gardiner DL, Jeansonne BG, Lemon RR. Current trends in endodontic treatment: report of a national survey. J Am Dent Assoc 1996; 127:133- 
141.

7. Jenkins SM, Hayes SJ, Dummer PM. A study of endodontic treatment carried out in dental practice within the UK. IntEndodJ 2001; 34:16-22.

8. Bjørndal L, Reit C. The adoption of new endodontic technology amongst Danish general dental practitioners. IntEndodJ 2005; 38:52-58.

9. Main SW, Ng'ang'a PM. Root canal treatment and pulpotomy in Kenya. East Afr Med J 1991; 68:243248.

10. Ahmed MF, Elseed AI, Ibrahim YE. Root canal treatment in general practice in Sudan. IntEndodJ 2000; 33:316-319.

11. Sjogren U, Hagglund B, Sundqvist G, Wing $K$; Factors affecting the long-term results of endodontic treatment. J Endod,. 1990; 16(10):498504.
12. European Society of Endodontology; Quality guidelines for endodontic treatment: consensus report of the European Society of Endodontology. IntEndod J., 2006; 39(12):921-30.

13. Gupta R, Rai R; The adoption of new endodontic technology by Indian dental practitioners: a questionnaire survey. J ClinDiagn Res., 2013; 7(11):2610-4.

14. Young GR, Parashos P, Messer HH. The principles of techniques for cleaning root canals. Australian Dental Journal. 2007; 52: S52-S63.

15. Goldfein J, Speirs C, Finkelman M, Amato R. Rubber dam use during post placement influences the success of root canaltreated teeth. Journal of Endodontics. 2013; 39: 1481-1484.

\section{How to cite this article:}

Jennifer Suhasini S and Manish Ranjan (2017) ' Awareness And Attitude Towards Obturation Techniques And Materials Used By Students In Dental Colleges Of Tamil Nadu', International Journal of Current Advanced Research, 06(04), pp. 3236-3238.DOI: http://dx.doi.org/10.24327/ijcar.2017.3238.0234 